\title{
Capital Market And The Transmission Channel Of The Monetary Policy: An Empirical Evidence On The Money View
}

Caroline Geetha, Universiti Malaysia Sabah, Malaysia

\begin{abstract}
The aim of this study is to find the relationship between the monetary transmission channels with the stock prices. The study utilizes the monthly data from 1990 to 2001 obtained from the Kuala Lumpur Stock Exchange Report and the monthly bulletin of the Central Bank of Malaysia. The result revealed that all the variables are non-stationary at the level form and stationary at the first difference. The Johansen Cointegration revealed that a long-run relationship does exist for the unanticipated changes in money supply, unlike the anticipated changes in money supply that only established a short-run relationship with stock prices. This is due to the level of monetization that is unable to eliminate the excess in the money market in the long run.
\end{abstract}

Keywords: monetary transmission channels, money market and capital market

\section{INTRODUCTION}

\section{Problem Statement}

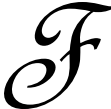

rom the beginning, Malaysia has sought to integrate its economy with the rest of the world by carrying out a series of liberalization policies in trade, investment and finance. These strategies have been very successful in directing the flow of foreign and domestic funds, thus changing the stock of money in the economy. The impact of the changes in the stock of money on the aggregate outcome can be explained using various monetary transmission channels. Traditionally, the impact of monetary transmission channel was explained using the money channel. When the stock of money increases, money supply will be greater than money demand. The cost of borrowing money will fall and the demand for capital goods and inventories will increase. This will eventually lead to an increase in the national income and finally explain the volatility in stock prices as proven by the study conducted by researchers like Hardouvelis (1987), Liljeblom and Stenius (1997) and Morelli (2002).

An increase in the stock of money can also influence the asset market directly through the interest rate channel by reducing the rate of interest. The transmission process will begin in the asset market. This is because the cost of information and transaction is lower for many assets compared to the cost of changing production, consumption and investment on durable goods. This will increase the price of assets. First, changes in the relative price of assets in the financial market can increase the aggregate demand. This will increase the price and output produced. At a higher price and output, more money is demanded for transactions. For those who predict that changes in price and output is persistent, they will sell bond and purchase equities. Second, anticipation would respond to initial impulse. Since information is still incomplete, the process of accumulating information will take place. This will increase the cost of production and eventually decrease the aggregate supply. Now with lower output and higher price, the demand for durable and all other assets will rise, but the demand for equities will fall.

Researchers also believe that as the stock of money expands, domestic firms can either finance their investment through loans or equity. According to Schumpeter (1911), when loans are given to firms - and with their existing equity, monitoring and supervision will help to increase productivity that will eventually lead to higher profits. Changes in the firm's profit would be an important indicator of equity performance in the capital market. 
Thus, money is important in creating the credit that can influence the capital market through the credit channel.

As firms expand and become more integrated with the world, they will create multiple cash flows that can further help to determine the value of the firms. These cash flows will be sensitive to the changes in the exchange rate. Therefore, the exchange rate channel is important in determining the competitiveness of the firms. On the other hand, when the stock market booms, it will attract more foreign capital. Higher demand for domestic currency will increase the exchange rate.

Thus it can be concluded that monetary transmission channels can link the monetary factors with the stock price. However, the effect of money stock on stock price can be further differentiated into anticipated and unanticipated following the rational expectation theory. There are two competing hypotheses. One model, called the neutrality theory, states that anticipated and unanticipated monetary shocks have no effect on real economic variables neither in the short run nor the long run, whereas the alternative model, called the non-neutrality theory of money, claims that due to wage contract and price stickiness, unanticipated changes in monetary shocks would at least have a strong impact on real economic variables in the short run.

A number of studies, including those of Grossman (1981), Urich and Wachtel (1981), Roley (1982) and Cornell (1983), found that the anticipated changes in money supply first influences the interest rate. An increase in the rate of interest can reduce the level of investment and the growth of output. In addition, the increase in the rate of interest can reduce the price of equity or financial assets produced by the financial institutions.

Friedman and Schwartz (1963) found that both anticipated and unanticipated changes in money supply could have a direct impact on the general price level with the assumption that velocity and transaction is constant. Acceleration in the general price level would encourage the government to be proactive and to practice a tight monetary policy by increasing the rate of interest and practicing a restrictive fiscal policy. As a result of the increase in both the rate of interest and tax, the corporate earnings of a firm will reduce and finally lead to a fall in stock prices. Thus, this argument also shows that the monetary policy and the fiscal policy are both complements in influencing the equity performance in the capital market.

In Malaysia, the studies that link the monetary transmission channels with the stock prices were studied by Fauzias, Noor Azuddin and Zaidi (2000), Muzaffar and Ahmad (1997) and Rim (2002). The study performed by Fauzias, Noor Azuddin and Zaidi (2000) used only two monetary transmission channels, the interest rate channel and the exchange rate channel. The sample of the study was further divided into two-time periods - before and after the currency turmoil. Both the variables are found to be significant in explaining the changes in the stock prices at both time periods in the long run. Rim (2002) also measured the impact of the exchange rate channel on 12 indices in Malaysia. The result revealed that the impact of exchange rate was only significant on five indices, such as the EMAS index, financial index, trade service index, industrial index and the industrial production index in the long run. Muzaffar and Ahmad (1997) used the money channel by converting the monetary aggregate M1 into divisia monetary aggregates. The researchers aimed to include the degree of moneyness by using weightage in this study. The composite index was used to represent the capital market in all the studies conducted in Malaysia.

The focus of this study is first to contribute additional empirical findings by showing the impact of the monetary transmission channels on the capital market. The study uses the money channel, the interest rate channel, the credit channel and the exchange rate channel. Second, the study also incorporates the rational expectation theory by distinguishing the monetary aggregate that represents the money channel into anticipated and unanticipated changes in money supply. Third, advancement in the field of econometrics will help to formulate models that integrate both the sectors in the short run and the long run. Fourth, complementing the monetary policy with the fiscal policy can explain the role of the government in influencing the indices.

\section{Objective}

The overall objective of this study is to establish a relationship between the monetary transmission channel with the stock prices. The specific objective of this study aims to highlight the money view of the monetary policy transmission mechanism in influencing the stock prices. 


\section{LITERATURE REVIEW}

\section{Transmission Mechanism of Monetary Policy According to Money View}

According to Mundell (1963), the IS-LM model was initially used to relate money with monetary aggregates. According to the money view, as the supply of money increases, the public's desire to hold portfolio outperforms the desire to actually hold money. Individuals tend to shift out of money holdings and into other financial assets. The increase in the demand for financial assets will eventually increase the price of the assets, creating a positive wealth effect. At the same time, the risk adverse investors will increase the demand for less risky financial assets. The increase in the demand for safe assets will create a negative substitution effect. Therefore, in the money view, an increase in the supply of money can create a positive wealth effect but a negative substitution effect for an individual. In addition, Bernanke and Gertler (1995) explain the money view by also claiming that when the money supply increases, firms can also increase their investment by increasing their demand for capital goods. This will eventually lead to higher profits. Higher profits will be reflected by equity performance in the stock market where the firm's share value will increase.

This is followed by the introduction of the rational expectation theory that makes it necessary to differentiate money supply from anticipated and unanticipated. The rational expectation theory has two competing models on money supply, called the neutrality theory, developed by Lucas (1972) and Sargent and Wallace (1975). It is often referred to as LSW proposition, which states that the anticipated changes in money supply would have no effect on real economic variables, neither in the short run nor the long run, whereas unanticipated changes in money supply should have profound impact on real economic variables in the short run. The alternative model developed by Phelps (1973) and Taylor (1975) claimed that due to wage contracts and price stickiness, anticipated changes in money supply would at least have a strong impact on real economic variables in the short run, which is often termed as the non-neutrality of monetary policies. This contest between the hypotheses generated tremendous contribution to the theoretical and empirical literature. Some supported the neutrality theory while others supported the nonneutrality theory. Most of the studies were conducted in the developed nation by Barro (1977), Attfield (1981), and Conarella and Pollard (1988), who supported the neutrality theory; but studies conducted in the developing nations, like the Latin American countries and India, which are not as monetized as the developed nations, showed otherwise. For example, Beladi and Samanta (1988) in India and Choudhry and Parai (1991) in Latin American countries found evidence of non-neutrality.

An alternative approach states that discrepancies between the nominal quantity of money demanded and the nominal quantity of money supplied are pivotal to the analysis of the transmission mechanism. Friedman (1983) claims that the quantity of money is independent and is subjected to the independent influence by the central bank. Thus, the role of the central bank to eliminate any form of excess balances is considered to have an important role in the transmission of the monetary policy. The process of elimination would create aggregate short-run economic consequences if money is active. An expansionary monetary shock that generates a short fall in the rate of interest can lead to changes in the expected returns of a planned portfolio. This would encourage investors to choose an alternative portfolio where the average money holdings will increase. If money is passive, the agent will be able to eliminate any form of excess balance and would not be able to create any aggregate short-run consequences.

Considering the money view, obviously the credit market is largely ignored in the standard IS-LM model and is restricted to a single portfolio equation. According to Bernanke and Gertler (1995), there are few implications that can be drawn. First, it makes no difference whether the banks hold loans or government securities as assets. Second, it makes no difference whether the borrowers obtain credit from the banks or other financial institutions. Third, money view assumes all the markets to be perfect. All the borrowers are homogenous from the viewpoint of the lenders. Thus, the banks cannot discriminate between the characteristics of different borrowers. Moreover, all the information obtained is assumed to be perfect. Hence, price is the only factor to clear the markets or to equilibrate the markets. Since this view is based on the notion that there are no externalities or market imperfections, a new view of monetary transmission emphasizing how asymmetric information and costly enforcement of contracts creates agency problems in financial markets was introduced. 
The empirical evidence that was carried out did not specifically explain the effect of each monetary transmission channel on the stock prices. The study only included the macroeconomic variables considered to influence stock prices. In addition, the method of analysis ranged from a simple graphical method to the latest development in the field of econometrics on time series analysis that used the VAR estimation method.

Sprinkel (1964) carried out the initial study that linked the money market and the capital market based on the money view. As the supply of money expands, Sprinkel (1964) believes that the public's desire to hold portfolio outperforms the desire to actually hold money. Individuals tend to shift out of money holdings to other financial assets. The increase in the demand for assets increases the price of the assets. He associated changes in money supply with stock prices and the relationship to business cycles in the economy. He also measures the unexpected changes in the growth rate of money by simply measuring the growth rate from one time to another time period. Initially he tested the monetary portfolio theory by using the visual presentation, such as the graphical method, but this revealed to be a weak technique when he encountered several problems. First, he faced difficulty in finding the accurate changes in a variable by examining their level graphically. Second, any graphical procedure tends to be biased and is subjected to the possibility of errors. Hence, he concluded that a statistical approach using the Ordinary Least Square Method should provide a far better result. The statistical method used provided a powerful test of the influence of money supply changes on stock price changes through regression. This method was able to explain the fraction of the variation in stock prices associated with the growth rate of money supply.

Sprinkel (1964) used data at different frequencies from 1918 to 1960. The dependent variable stock prices were regressed with the independent variable growth rate of money supply. The result revealed that the use of money supply, as an indicator for future stock market movements, cannot be executed without incorporating business cycle turning points such as peaks and trough. The lag created between the changes in money supply and stock prices was used to solve the problem. He concluded that money changes would lead the stock prices by two months when the economy faces upturn and by fifteen months when the economy faces a downturn.

Palmer (1970) extended Sprinkel's graphical method by using 6 months moving averages of monthly percentage changes in stock prices to represent the capital market. Simple correlation with lagged data terms used showed strong correlation between the growth rate of money supply and the stock prices. But when Palmer (1970) explored the relationship between the two variables graphically and by regression using monthly changes in stock prices and the current and five lags of the monetary variables, the result showed a weak relationship between the variables.

Keran (1971) used quarterly data of stock prices as the dependent variable and current and lagged changes in money supply, real GNP, consumer price index and lagged levels of real corporate earnings as the independent variables. The result revealed a strong coefficient of determination (0.98) between the stock prices and the real economic activities. The findings were supported by Homa and Jaffee (1971).

Hamburger and Kochin (1972) found the relationship between stock prices and the monetary variables by using the formula to determine equity pricing. They claim that all the determinants of equity pricing, such as liquidity effect, risk-free premium effect and earning effect, will be influenced by money supply which indirectly influences the stock prices.

The findings of Hamburger and Kochin (1972) were supported by Rozeff (1975). Rozeff (1975) strongly agrees that when the monetary policy is tightened, stock prices will decrease, and when the monetary policy is loosened, stock prices will increase. Contractionary and the expansionary monetary policy takes place by using the monetary instruments, such as margin requirement, reserve requirement, discount rate, federal fund rate, and the statement from the Federal Reserve Board. According to Anderson and Jordon (1967), the central bank also changes bank reserves and finally the money supply by buying and selling bonds.

An alternative view by Cooper (1972) found that changes in money supply and stock prices seem to refute earlier findings that if the capital market is efficient, past information, such as money supply changes, could not be used to predict stock prices. Therefore, another test should be used to determine the efficiency of the capital market. Cooper (1972) develops a combination of the Simple Quantity Theory of Money Model and the Efficient Market 
Model. Since the Simple Quantity Theory of Money does not take into consideration the development in the business finance literature, the Efficient Market Model was used. In an efficient market, new information is rapidly incorporated into the price of the asset sold in the market, so the current asset prices reflect all current available information. Investors need not extend their resources to obtain additional information.

According to Cooper (1972), it is useful to designate whether the Efficient Market Model is in the strong, intermediate and weak form. When $\mathrm{I}=\mathrm{I}^{\mathrm{H}}$, it represents all available information and the model is in its strong form. If only past information is available, then the model presents the weak form $\mathrm{I}=\mathrm{I}^{\mathrm{W}}$. The intermediate form of the model defines $\mathrm{I}$ as $\mathrm{I}^{\mathrm{M}}$. The weak form of the model is a subset to the intermediate and the intermediate form is a subset to the high form of the model.

Cooper (1972) used the Standard and Poor Composite Index, Dow Jones Industrial Index and Fishers Index to represent stock prices. The three indexes were chosen after carrying out a preliminary analysis indicating similar characteristics. When a cross-spectral analysis was conducted, they showed coherences greater than 0.85 . In addition, the relationship between money supply and each of the indexes were the same. The return for the period $t$ is the dividend yield for period $t$ and the percentage changes in the price index. When the definition of return was compared with the simple percentage price change, returns were found to be identical with the percentage changes in the stock prices. Cross-spectral analysis confirmed the statement by showing a coherence greater than 0.99. Therefore, Cooper (1972) used the return on stocks as a proxy for the capital market instead of using the price of the stock itself. The study revealed that M1 is a better measurement of the monetary aggregate compared to M2 and the relationship between the monetary base and stock returns was stronger than the relationship between money supply and stock returns.

Sprinkel's (1964) study was also extended by Fama and Schwert (1977). Fama and Schwertz (1977) provided evidence that common stock returns have a positive and significant relationship with all the real variables, but showed a negative relationship with the rate of inflation. Fama and Schwertz (1977) states that when we anticipate higher growth rate in the economic activity, the rate of inflation will be low. Higher growth rate in the real economic variables will increase the demand for stock, thus increasing its price. Fama and Schwertz (1977) summarizes real economic activity with real variables, such as real GDP, capital expenditure, and the growth rate of money demand obtained monthly, quarterly and annually based on the availability of the data. Multiple regressions were formed to show the relationship between the stock returns and the real variables. First, the rate of inflation was regressed with the expected rate of return obtained from the Treasury bill's rate. Second, the demand for money function was formed where the real money balance was made the dependent variable while the nominal money and the general price level were the independent variable. As proposed by the Philip Curve, the relationship between the real activity and the rate of inflation was negative, while the relationship between the rate of inflation and the real output was positive. Third, the stock returns were regressed with a wide range of real variables, such as capital expenditure, real rate of return on capital and the real GDP. The result documented strong positive relationship between the stock returns and the real variables. Fourth, stock returns were regressed separately with the rate of inflation and the growth rate of money. The higher-than-expected inflation rate caused higher growth rate in money supply causing a shift from non-interest bearing money to financial assets like common stocks, which lowers the expected real return on assets. It can be concluded that the study carried out by Fama and Schwertz (1977) indicates that money supply does not explicitly treat the relationship between money supply and the stock returns, but the underlying assumptions in the Simple Quantity Theory of Money can be used to derive the relationship.

Freidman and Schwartz (1963) supported the relationship between money supply and stock prices in the U.S. using the long-run demand function. The long-run money demand function states that real demand for money is positively related to real income, negatively related to the rate of return and could be either positively or negatively related to stock prices. This is because when money supply increases, nominal wealth will increase, creating a positive wealth effect; but a negative substitution effect can also be created when the expected rate of return increases for risky assets compared to the safe assets. A risk adverse investor would demand less risky financial assets. The result was supported by Mc Cornac (1994) based on his findings in Japan.

Rapach (2001) claims that general economic conditions will determine the price of financial assets in the economy. Changes in the economic conditions, known as macroeconomic shocks, consist of changes in money 
supply, aggregate demand and aggregate supply. These macro shocks figure prominently in theoretical and empirical models of the macro economy and are generally regarded as important sources of fluctuations in aggregate real output, interest rates and the price level. Lastrapes and Selgin (1995) confirm that each macro shocks have an important impact on the real sector through the financial sector.

Darrat (1994) believes that among the macroeconomic variables, the budget deficit is the main macroeconomic variable that can help to explain the changes in the price of financial assets. This is due to the fact that budget deficit represents the fiscal policy of a nation. Darrat (1994) claims that fiscal policy is a complement to the monetary policy in stabilizing the economy of a nation. When there is unemployment, the government practices expansionary fiscal policy by increasing government spending or reducing tax. This will increase the national income and eventually the purchasing power of the nation. The demand for financial assets will increase eventually leading to an increase in the price of the financial assets. In contrast, when there is inflation, the government tightens the fiscal policy by reducing government spending or increasing tax. This will decrease the national income and the purchasing power of the nation. The demand and the price of the financial assets will fall. In the study conducted by Darrat (1994), the fiscal policy was further distinguished into anticipated changes in the fiscal policy and unanticipated changes in the fiscal policy in line with the rational expectation theory. The study concluded that anticipated changes in the fiscal policy can influence stock prices in the developing nation while unanticipated changes in fiscal policy are responsible in explaining the changes in the stock prices for the developed nation. Therefore, it can be concluded that fiscal policy can be used as a complement to the monetary policy. It is important in explaining the changes in the aggregate outcomes, especially the behavior of the stock market volatility.

For a number of years, much interest has been shown in the behavior of stock market volatility. The use of the macroeconomic variables, in relation to stock return volatility, was examined by Schwartz (1978) using the U.S. data. The macroeconomic variables used were the rate of inflation, industrial production index and the money supply. Liljeblom and Stenius (1997) conducted a similar study based on the Finnish data found that between onesixth and more than two-thirds of changes in the stock market volatility were related to macroeconomic volatility, namely, inflation, industrial production, and money supply. This is because the level of corporate equity on the aggregate level will depend on the health of the economy. It is plausible that a change in the level of uncertainty about the future macroeconomic conditions would produce a proportional change in security return volatility. Morelli (2002) claims that returns on stocks can be calculated by the changes in the stock prices between two time periods. The macroeconomic variables selected to explain the volatility of the stock returns include the industrial production, real retail sales, money supply, the exchange rate and the rate of inflation.

But a number of recent studies conducted by researchers, such as Grossman (1981), Urich and Wachtel (1981), Roley (1982), and Cornell (1983), examined that the impact on the changes in money supply is different if there is an unexpected announcement in money supply. There are, however, two competing interpretations of the result. First, agents may believe that the central bank will react to unexpectedly high money growth by quickly moving to a more restrictive monetary policy that would lead to a higher interest rate. The anticipation of higher rates in the near future causes agents to sell securities immediately, forcing interest rates to further increase upwards and causing the real stock prices to decline. The second interpretation is that agents revise upward their expectations of inflation when a positive money stock surprise occurs. Higher expected inflation was found to have a negative effect on stock prices.

Hardouvelis (1987) differentiated announcements by the central bank to monetary and non-monetary news. Stock prices responded primarily to monetary news. Among all stock price indexes used, the New York Stock Exchange (NYSE) showed the strongest reaction because the cash flows of financial companies are directly affected by monetary developments. Another monetary announcement is the rate of inflation. A direct and negative impact could emerge between the expected inflation and stock prices. This is because the nominal rate of interest can be divided into two components, the real rate of interest and the rate of inflation. When the rate of inflation increases, the nominal rate of interest will increase, thus increasing capital expenditure in the country and eventually creating a fall in the price of stocks. The second channel, commonly known as the expected inflation hypothesis, explains that inflation surprises may affect stock price occurrences if agents believe that policy makers react to inflation news with restrictive policies, which leads to a reduction in cash flows for firms, thus reducing the stock prices. The third monetary news is the change in the rate of discount. Wald (1970) claims that changes in the rate of discount are 
associated with monetary policy. An increase in the rate of discount would reduce the market interest rate and stock prices. This is known as the expected real interest rate hypothesis. Hardouvelis (1987) showed that non-monetary announcement is found to be very weak, but significant in explaining the changes in the stock prices. The variables chosen to represent the non-monetary news would be the trade deficit, the rate of unemployment and personal income.

Advancement in the field of econometrics was incorporated by Thornton (1991) and Choudhry (1996) in establishing a relationship between the monetary transmission mechanism and the stock prices. Thornton (1991) used the Granger Causality test to investigate the lead-lag relationship between money supply, real output and stock prices in U.K. The results suggest that the stock prices tend to lead the money supply, monetary base tends to lead real output, the volatility in money supply will create volatility in stock prices, and the real GDP volatility leads the money supply. The results were found to be consistent with the findings of Cooper (1972) and Rozeff (1975).

Choudhry's (1996) attempt to integrate the monetary variables and the stock prices in Canada and the USA began by initially regressing the variables using the Ordinary Least Square Method. Since the data used are time series, a unit root test was conducted to identify whether the variables are stationary or non-stationary. If the variables were stationary, then the regression estimated will not be biased; but if the variables were non-stationary, the Ordinary Least Square method used would be inappropriate. Thus, the Augmented Dickey Fuller test was conducted to identify whether the variables were stationary in the level form. The unit root was also performed on the first differences of each time series to test for higher order unit roots. Differencing each series one time leads the variables to be stationary.

Choudhry (1996) also used the error correction model to show the dynamic nature of the money demand function in first differences. In addition, the Johansen Co-integration Method was used to find the long-run relationship between the two variables. The result showed evidence that there is a short-run and a long-run relationship between money supply and the stock prices in both the U.S. and Canada.

In Malaysia, Muzaffar and Ahmad (1997) initially studied the study that links the monetary transmission mechanism and the stock prices using the money channel in Malaysia. The commodity index was used as a proxy for stock prices, while different measurement of monetary variables, such as the traditional simple sum aggregates and the divisia monetary variables, were used to represent the money channel. The result confirmed that there is a long-run relationship between the money channel and the stock prices supporting the non-neutrality theory of money.

The study performed by Fauzias, Noor Azuddin and Zaidi (2000) used only two monetary transmission channels - the interest rate channel and the exchange rate channel. The sample of the study was further divided into two time periods - before and after the currency turmoil. Both the variables are found to be significant in explaining the changes in the stock prices at both time periods in the long run.

\section{DATA AND METHODOLOGY}

\section{Data}

The macroeconomic data under study consist of the monthly monetary variables and non-monetary variables taken from the Bank Negara Monthly Bulletin Economic Report and the Ministry of Finance Monthly Financial Reports. The sample of the study ranges from January 1990 to December 2001. The monetary transmission channels included in this study consist of the money channel, the interest rate channel, the exchange rate channel and the credit channel. Attempts in identifying the ideal measurement of money supply to represent the money channel began with preliminary analysis involving all the measurements of money supply, M1, M2, and M3 though Muzaffar and Ahmad (1997) support that monetary aggregate M1 is the best indicator of money supply.

Further in line with the rational expectation theory, Barro's (1977) and Yusuff's (1993) two-step estimation method was used to differentiate the money channel into anticipated and unanticipated changes in money supply. Anticipated changes in money supply will be represented by the current value of the money supply, while the 
unanticipated changes in money supply will be represented by the residuals obtained from regressing the current value of money supply with the lagged two values of the money supply. Later, the residuals were converted to variance by powering the values of the residuals by two. This was done to provide a better representation of the unanticipated value of the money supply.

The non-monetary variables used in this study consist of the gross domestic product and the inflation rate. The industrial production index is used as a proxy for gross domestic product since the frequency of the gross domestic product data are yearly, while the industrial production index is in line with the monthly data used in this study. The consumer price index with the base year of 1980 is used to represent the rate of inflation. The monthly data of the budget deficit that represents the fiscal policy were obtained from the Ministry of Finance Monthly Financial Reports.

The market index used in this study is the Kuala Lumpur Composite Index (KLCI). The industry indices are obtained from Kuala Lumpur Stock Exchange Reports. The Kuala Lumpur Composite Index was used because it is composed of 100 blue chip stocks with large market capitalization.

\section{Model}

Based on the discussion in Section 1.3, the stock of money can influence the stock prices through several monetary transmission channels. Initially, the money view used the money channel to explain its influence on the aggregate outcomes and eventually the stock prices. Muzaffar and Ahmad (1997) used the money channel to explain its influence on the price of the composite index. They converted the monetary aggregate of money supply M1 into divisia monetary aggregates in order to incorporate the degree of moneyness through the use of weightage. Fauzias, Noor Azuddin and Zaidi (2000) used the interest rate channel and the exchange rate channel to find the relationship between the interest rate and exchange rate with the composite index. The study that used annual data was also divided into two sub-periods - before and after the currency turmoil. The study also incorporated nonmonetary variables, like GDP and trade balance, to represent the economic cycles that provide internal and external news for the reaction of the investors.

The study aims to add empirical contribution to the literature that integrates the monetary transmission channels with the stock prices. As such, the current study aims to contribute the following. First, the data in this study consists of monthly data from 1990:1 to 2001:12, unlike the earlier studies that used the quarterly and annual data. Second, since the rational expectation theory is incorporated, the money channel is further distinguished into anticipated and unanticipated changes in money supply. Fourth, the composite index is used to represent the behavior in the stock market.

To test the impact of the money channel in the monetary transmission mechanism on the stock prices, the studies by Muzaffar and Ahmad (1997) and Barro (1977) were used. The study by Muzaffar and Ahmad (1997) that used the money channel to explain the behavior of the stock prices was extended in this study by using Barro's (1977) method of incorporating the rational expectation theory. This was done by differentiating money supply into anticipated changes in money supply (AM) and unanticipated changes in money supply (UM). Since there were correlation between the anticipated changes in money supply (AM) and unanticipated changes in money supply (UM), both variables were used as an independent variable in separate equations, (4.1) and (4.2).

With this, the following equations are formed:

$\mathrm{SP}_{\mathrm{t}}=\alpha_{0}+\alpha_{1} \mathrm{AM}_{\mathrm{t}}+\alpha_{2} \mathrm{GDP}_{\mathrm{t}},+\alpha_{4} \mathrm{INF}_{\mathrm{t}}+\varepsilon_{\mathrm{t}}$

$\mathrm{SP}_{\mathrm{t}}=\beta_{0}+\beta_{1} \mathrm{UM}_{\mathrm{t},}+\beta_{2} \mathrm{GDP}_{\mathrm{t}}+\beta_{3} \mathrm{INF}_{\mathrm{t}}+\varepsilon_{\mathrm{t}}$

where SP stands for the composite index and AM stands for the anticipated changes in money supply, while UM stands for the unanticipated changes in money supply, GDP represents the national output, and INF is the rate of inflation. $\alpha_{0}, \alpha_{1}, \alpha_{2}, \alpha_{3}, \beta_{0}, \beta_{1}, \beta_{2}$ and $\beta_{3}$ are the estimated coefficients. All the variables are converted into logarithmic form. 
Anticipated changes in money supply (AM) was obtained from the published data of the Bank Negara Malaysia Monthly Bulletin Economic Reports while the unanticipated changes in money supply (UM) was obtained from regressing the current value of the changes in money supply $\left(M_{t}\right)$ as the dependent variable and the lagged value of the changes in money supply $\left(\mathrm{M}_{\mathrm{t}-1}, \mathrm{M}_{\mathrm{t}-2}\right)$ as the independent variables. The residual $(\varepsilon)$ obtained from the regression above will be converted into variance $\left(\sigma^{2}\right)$ by powering the value of the residuals $(\varepsilon)$ by two. The variance $\left(\sigma^{2}\right)$ will represent the unanticipated changes in money supply (UM). To represent the anticipated and unanticipated changes in money supply, all three measurements of the money supply, which consist of the monetary aggregate M1, M2 and M3, are used. This will help to indicate the best measurement of money supply that could explain the changes in the stock prices in the capital market.

In addition, variables like national output and the rate of inflation were also used as independent variables in equations in (4.1) and (4.2). According to Muzaffar and Ahmad (1997), the national output will be able to incorporate the changes in the economy based on internal and external news of the country. Ghatak (1994) also finds the rate of inflation as the best proxy for the opportunity cost of holding money in developing nations where financial dualism exists. The composite index was used as the dependent variable to represent the stock prices.

In contractionary monetary policy, consumers and firms will anticipate price and output to fall due to decrease in the aggregate demand. This will increase real wages and workers will increase the supply of labor to firms. As a result, aggregate supply will shift which will increase productivity. At a lower price level, output will remain unchanged. Therefore, anticipated changes in money supply cannot influence the economic activity and eventually the stock prices. However, according to the rational expectation theory, consumers and firms cannot anticipate changes in macroeconomic policies. Employers tend to decrease nominal wages when government implements a contractionary monetary policy. Since workers do not anticipate changes in monetary policy, they will misperceive any fall in nominal wages indicating a fall in real wages. Workers do not know that a decrease in money supply will decrease the price. They also do not know that the real wages would actually increase. Supply of labor will shift the aggregate supply curve to the left, which will decrease the price and the output produced. Thus, it can be concluded that unanticipated changes in money supply can lead to a fall in productivity and eventually a fall in the stock prices. The New Classical economics claim that anticipated changes in money supply cannot influence the stock prices in the short run, but unanticipated changes in money supply will influence the stock prices both in the short run and the long run. As for the Keynesian view, both anticipated and unanticipated changes in money supply can influence the stock prices in the short run and the long run. It is also expected to positively relate to stock prices. Similarly, the GDP is also expected to increase the productivity, resulting in higher profit earned by firms. This will eventually be shown by the increase in stock prices. In contrast, the inflation rate is expected to have a negative relationship with the stock prices. This is because when the inflation rate increases, the government will implement a tight monetary policy. This will increase the rate of interest. Demand for bonds will increase but the demand for stocks will fall resulting in a decrease in stock prices.

Based on the various economic views, it can be hypothesized that if the development and diversification of the financial structure are able to absorb the changes in the monetary aggregate, both anticipated and unanticipated changes in money supply will not be able to influence the changes in the price of both the indices in the short run and the long run. This will support the findings obtained by researchers like Barro (1977), Hanson (1980), Shehy (1980), Conarella and Pollard (1988) that money is neutral in developed nations. Otherwise, if both the anticipated and unanticipated changes in money supply are able to influence the stock prices in the short and the long run, it can be concluded that money is not neutral supporting the studies conducted by Beladi and Samanta (1988) in India, Choudhry and Parai (1991) in Latin American countries and Muzaffar and Ahmad (1997) in Malaysia.

\section{Unit Root Test}

Before the estimation can be carried out, all the variables should be tested to determine if the variables are stationary or non-stationary in levels or first differences. The stock prices of the composite index and the monetary variables, like the monetary aggregates, the GDP, and the inflation rate, have been well approximated by the time series models. As a preliminary analysis, each series is first checked for a unit root (non-stationary) using the Augmented Dickey Fuller (ADF) and the Philip-Perron (PP) tests, which allow for a linear time trend. Note that the usefulness of the Philip-Perron (1988) test over the Augmented Dickey Fuller test allows for the possibility of heterokedastic error terms. The lag length in the Philip-Perron (1988) test is selected based on the Newey-West 
criteria. The asymptotic distribution of the Augmented Dickey Fuller and the Philip-Perron tests is the same as Mac Kinnon's critical value of $-3.4865,-2.8859$ and -2.5796 for 1 percent, 5 percent and 10 percent respectively.

\section{Co-integration Test}

Despite being individually non-stationary, a linear combination of the two or more time series can be stationary. Cointegration of two or more time series suggests that there is a long-run relationship or equilibrium between them. If the variables are found to be stationary at level one, then the determination of optimal lag length is performed based on the likelihood ratio test or Akaike Information Criteria (AIC) on the traditional Vector Auto Regressive (VAR). The smaller the value of the information criteria, the better the model.

\section{The Vector Error Correction Modeling}

If the variables are cointegrated and there is a unique number of cointegrating vectors, the vector error correction modeling can be carried out. Using the $t$ test, the error correction term should be significant at 1 percent, 5 percent and 10 percent significance levels to establish a short-run relationship between the variables.

\section{FINDINGS}

\section{The Unit Root Test Results}

All the variables are unable to reject the null hypothesis of a unit root in the level form except for the unanticipated changes in money supply for M1, M2 and M3. The estimated values are found to be greater than the Mac Kinnon's critical value at 1 percent and 5 percent significance levels. As for the series of unanticipated changes in money supply of M1, M2 and M3, all the calculated values are larger than the Mac Kinnon's critical value at 1 percent and 5 percent significance levels. The calculated ADF for each first differenced series is greater than its critical value, suggesting that the null hypothesis for each first differenced series has one unit root which can be rejected at 1 percent significance level.

The Philip-Perron test at level and first difference also shows that the estimated values for each series are smaller than the Mac Kinnon's critical value at 1 percent and 5 percent significance levels, except for the unanticipated changes in money supply for the monetary aggregates M1, M2 and M3. As such, the null hypothesis failed to be rejected. The entire series suffered a unit root problem, except for the unanticipated changes in money supply M1, M2 and M3. The estimated Philip-Perron for the each first differenced series also shows that the estimated value is greater than their critical values in all cases, suggesting the null hypothesis for each first differenced series has one unit root which can be rejected at 1 percent significance level. Similarly, the result obtained from the Philip-Perron test is also consistent with the Augmented Dickey Fuller test. The first difference of all the variables in the series is stationary. This result allows the cointegration analysis to be carried out as suggested by Johansen and Juselius (1990).

\section{Co-Integration Test Results for the Composite Index}

When each monetary transmission channel is tested with the composite index to determine whether the variables are cointegrated over the sample period, the following results were obtained.

Table 1 (a)

Johansen-Juselius Maximum Likelihood Ratio Test for Cointegrating Vector Between the Money Channel that is Represented by the Anticipated Changes in Money Supply, M1 with the Composite Index (KLCI)

\begin{tabular}{|c|c|c|c|}
\hline Null hypothesis & & No. of lag=2 & Critical value 0.01 \\
\hline & Likelihood ratio & Critical value 0.05 & 54.46 \\
\hline $\mathrm{r}=0$ & 43.62349 & 47.21 & 35.65 \\
\hline $\mathrm{r} \leq 1$ & 15.19516 & 29.68 & 20.04 \\
\hline $\mathrm{r} \leq 3$ & 2.572814 & 15.41 & 6.65 \\
\hline
\end{tabular}

$* *(* * *)$ denotes rejection of the hypothesis at 5 percent (1 percent) significance level. 
Table 1(b)

Normalized Cointegrating Coefficients Between the Anticipated Changes in Money Supply, M1 and the Composite Index (KLCI)

\begin{tabular}{|c|c|c|c|c|}
\hline $\log ($ KLCI) & $\log (\mathbf{A M 1})$ & $\log (\mathbf{G D P})$ & $\log (\mathbf{I N F})$ & $\mathbf{C}$ \\
\hline 1.000 & -1.673698 & 1.756126 & 0.395783 & -6.867010 \\
\hline & $(0.16395)$ & $(0.20423)$ & $(0.40059)$ & \\
\hline Loglikelihood & 834.7678 & & & \\
\hline
\end{tabular}

The value in the parentheses represents the estimated $t$ value of the normalized coefficients.

The critical values are 2.576 for 1 percent $(* * *)$ and 1.960 for 5 percent (**) respectively.

It can be observed from Table 1(a) that the number of cointegrating vectors, as indicated by the Likelihood Ratio test, cannot reject the null hypothesis of no co-integrating vector $(r=0)$ at 5 percent significance level. In Table 1(b), the normalized cointegrating coefficients show that the estimated t value for all the variables is less than the critical value of $t$ at the 5 percent significant level. This indicates there is no long-run relationship between the anticipated changes in money supply M1 and the composite index.

Table 2(a)

Johansen-Juselius Maximum Likelihood Ratio Test for Cointegrating Vector Between the Money Channel that is Represented by the Anticipated Changes in Money Supply M2 with the Composite Index (KLCI)

\begin{tabular}{|c|c|c|c|}
\hline Null hypothesis & & No. of lag=2 & Critical value 0.01 \\
\hline & Likelihood ratio & Critical value 0.05 & 54.46 \\
\hline $\mathrm{R}=0$ & 39.68315 & 47.21 & 35.65 \\
\hline $\mathrm{R} \leq 1$ & 17.01302 & 29.68 & 20.04 \\
\hline $\mathrm{R} \leq 2$ & 4.268465 & 15.41 & 6.65 \\
\hline
\end{tabular}

$* *(* * *)$ denotes rejection of the hypothesis at 5 percent (1 percent) significance level

Table 2(b)

Normalized Cointegrating Coefficients Between the Anticipated Changes in Money Supply M2 with the Composite Index (KLCI)

\begin{tabular}{|c|c|c|c|c|}
\hline $\log ($ KLCI) & $\log (\mathbf{A M 2})$ & $\log (\mathbf{G D P})$ & $\log (\mathbf{I N F})$ & $\mathbf{C}$ \\
\hline 1.000 & -0.814162 & 0.335465 & 6.424924 & -30.01205 \\
\hline & $(0.18945)$ & $(0.22343)$ & $(1.33122)$ & \\
\hline Loglikelihood & 713.7786 & & & \\
\hline
\end{tabular}

The value in the parentheses represents the estimated $t$ value of the normalized coefficients. The critical values are 2.576 for 1 percent $(* * *)$ and 1.960 for 5 percent $(* *)$ respectively.

In Table 2(a), when the monetary aggregate anticipated changes in money supply M1 is replaced by the anticipated changes in money supply, M2, the Likelihood Ratio test cannot reject the null hypothesis of no cointegrating vectors at 5 percent significance level. The normalized cointegrating coefficients displayed in Table 2(b) have an estimated $t$ value that is less than the critical value of $t$ at 5 percent significance level. Thus, there is no long-run relationship between the anticipated changes in money supply M2 and the composite index.

Table 3(a)

Johansen-Juselius Maximum Likelihood Ratio Test for Cointegrating Vector Between the Money Channel that is Represented by the Anticipated Changes in Money Supply M3 with the Composite Index (KLCI)

\begin{tabular}{|c|c|c|c|}
\hline Null hypothesis & No. of lag=2 & Critical value 0.01 \\
\hline & Likelihood ratio & Critical value 0.05 & 54.46 \\
\hline $\mathrm{r}=0$ & 36.22762 & 47.21 & 35.65 \\
\hline $\mathrm{r} \leq 1$ & 18.17486 & 29.68 & 20.04 \\
\hline $\mathrm{r} \leq 3$ & 8.650721 & 15.41 & 6.65 \\
\hline
\end{tabular}

$* *(* * *)$ denotes rejection of the hypothesis at 5 percent $(1$ percent) significance level. 
Table 3(b)

Normalized Cointegrating Coefficients between the anticipated changes in money supply M3 and the composite index (KLCI)

\begin{tabular}{|c|c|c|c|c|}
\hline $\log ($ KLCI) & $\log (\mathbf{A M 3})$ & $\log (\mathbf{G D P})$ & $\log (\mathbf{I N F})$ & $\mathbf{C}$ \\
\hline 1.000 & -1.871470 & 2.718306 & 2.349277 & -19.63285 \\
\hline & $(0.360 .37)$ & $(0.58550)$ & $(0.69993)$ & \\
\hline Loglikelihood & 971.9055 & & & \\
\hline
\end{tabular}

The value in the parentheses represents the estimated $t$ value of the normalized coefficients. The critical values are 2.576 for 1 percent $(* * *)$ and 1.960 for 5 percent $(* *)$ respectively.

In Table 3(a), the monetary aggregate M3 is used to represent the anticipated changes in money supply. The Likelihood Ratio test rejects the null hypothesis of no cointegrating vectors at 5 percent significance level. The normalized cointegrating coefficients also show that the estimated $\mathrm{t}$ values for all the variables are less than the critical value at 5 percent significance level (refer to Table 3(b)). Thus, it can be concluded that the anticipated changes in M3 also cannot influence the price of the composite index in the long run.

The findings support the neutrality theory of money introduced by Lucas (1972) and Sargent and Wallace (1975). According to the LSW propositions, the anticipated changes in money supply would have no effect on real economic variables in the short run nor the long run. Some of the studies conducted in the developed nations by Barro (1977), Barro and Rush (1980), Hanson (1980), Shehy (1982), Artfield (1981), Conarella and Gorston (1983), and Chein and Steindl (1987) supported the findings obtained in this study that anticipated changes in money supply do not influence the changes in both the indices in the long run. Studies conducted by Muzaffar and Ahmad (1997) do not support the findings obtained in this study. The researchers found that anticipated changes in money supply are able to influence the price of the composite index in the long run. Therefore, money is non-neutral in the long run.

With the introduction of the rational expectation theory, the money channel is further analyzed by converting all the monetary aggregates of M1, M2, and M3 into unanticipated changes in money supply. The following findings were obtained.

Table 4(a)

Johansen-Juselius Maximum Likelihood Ratio Test for Cointegrating Vector Between the Money Channel that is Represented by the Unanticipated Changes in Money Supply M1 with the Composite Index (KLCI)

\begin{tabular}{|c|c|c|c|}
\hline Null hypothesis & & No. of lag=2 & Critical value 0.01 \\
\hline & Likelihood ratio & Critical value 0.05 & 54.46 \\
\hline $\mathrm{r}=0$ & $94.24205^{* * *}$ & 47.21 & 35.65 \\
\hline $\mathrm{r} \leq 1$ & 17.71201 & 29.68 & 20.04 \\
\hline $\mathrm{r} \leq 2$ & 4.894336 & 15.41 & 6.65 \\
\hline
\end{tabular}

$* *(* * *)$ denotes rejection of the hypothesis at 5 percent (1 percent) significance level

Table 4(b)

Normalized Cointegrating Coefficients Between the Unanticipated Changes in Money Supply M1 and the Composite Index (KLCI)

\begin{tabular}{|c|c|c|c|c|}
\hline $\log ($ KLCI $)$ & $\log (\mathbf{U M 1})$ & $\log (\mathbf{G D P})$ & $\log ($ INF $)$ & C \\
\hline 1.000 & -517.6357 & 0.500286 & 0.231179 & -11.5333 \\
\hline & $(235.546)^{* * *}$ & $(0.55118)$ & $(2.05621)^{* *}$ & \\
\hline Loglikelihood & 1120.794 & & & \\
\hline
\end{tabular}

The value in the parentheses represents the estimated t value of the normalized coefficients. The critical values are 2.576 for 1 percent $(* * *)$ and 1.960 for 5 percent $(* *)$ respectively. 
In Table 4(a), the Likelihood Ratio is found to be significant at 1 percent significance level, under the null hypothesis of no cointegrating vector. This means that when the unanticipated changes in money supply M1 are used to represent the money channel, the null hypothesis is rejected at 1 percent significance level. This means there is at least one cointegrating vector for the period of the study. As for Table 4(b), it shows the interrelationship among the unanticipated changes in money supply M1, GDP, and INF with the composite index. The unanticipated changes in money supply M1 have a positively significant relationship with the composite index at 1 percent significance level. This is because the estimated $t$ value (235.546) is found to be greater than the critical value of $t$ (2.576) at 1 percent significance level. As for the rate of inflation, the estimated $t$ value of 2.05621 is found to be greater than the critical value of $\mathrm{t}(1.960)$ at 5 percent significance level. The rate of inflation is negatively significant in explaining the changes in the composite index. The national income is insignificant in explaining the changes in the composite index because the estimated $t$ value of 0.55118 is less than the critical value of $t(1.960)$ for 5 percent significance level. Thus, it can be concluded that unanticipated changes in money supply M1 and the rate of inflation are found to be in line with the economic theory in explaining the changes in the composite index.

Table 5(a)

Johansen-Juselius Maximum Likelihood Ratio Test for Cointegrating Vector Between the Money Channel that is Represented by the Unanticipated Changes in Money Supply M2 with the Composite Index (KLCI)

\begin{tabular}{|c|c|c|c|}
\hline Null hypothesis & & No. of lag=2 & Critical value 0.01 \\
\hline & Likelihood ratio & Critical value 0.05 & 54.46 \\
\hline $\mathrm{r}=0$ & $211.4267 * * *$ & 47.21 & 35.65 \\
\hline $\mathrm{r} \leq 1$ & 17.75412 & 29.68 & 20.04 \\
\hline $\mathrm{r} \leq 2$ & 4.753265 & 15.41 & 6.65 \\
\hline
\end{tabular}

$* *(* * *)$ denotes rejection of the hypothesis at 5 percent (1 percent) significance level

Table 5(b)

Normalized Cointegrating Coefficients Between the Anticipated Changes in Money Supply M2 and the Composite Index (KLCI)

\begin{tabular}{|c|c|c|c|c|}
\hline $\log (\mathbf{K L C I})$ & $\log (\mathbf{U M 2})$ & $\log (\mathbf{G D P})$ & $\log (\mathbf{I N F})$ & $\mathbf{C}$ \\
\hline 1.000 & 9.309647 & 0.457424 & -2.052831 & -1.574455 \\
\hline & $(5.82520)^{* * *}$ & $(0.73958)$ & $(3.77997)^{* * *}$ & \\
\hline Loglikelihood & 618.9967 & & & \\
\hline
\end{tabular}

The value in the parentheses represents the estimated $t$ value of the normalized coefficients. The critical values are 2.576 for 1 percent $(* * *)$ and 1.960 for 5 percent $(* *)$ respectively.

When the unanticipated changes in money supply M1 are replaced by the unanticipated changes in money supply M2, the Likelihood Ratio is found to be significant at 1 percent significance level. Thus the null hypothesis of no cointegrating vectors can be rejected. There is at least one cointegrating vector. The normalized cointegrating coefficients for both unanticipated changes in money supply M2 and the rate of inflation are negatively and positively significant at 1 percent significance level respectively. This is because the estimated $t$ value for the unanticipated changes in money supply M2 (5.82520) and the rate of inflation (3.77997) are greater than the critical value of $t$ (2.576) at 1 percent significance level. All other variables are insignificant at 1 percent significance level; but the coefficient signs are not in line with the economic theory (refer to Table 5(a) and Table 5(b)).

Table 6(a)

Johansen-Juselius Maximum Likelihood Ratio Test for Cointegrating Vector Between the Money Channel that is Represented by the Unanticipated Changes in Money Supply M3 with the Composite Index (KLCI)

\begin{tabular}{|c|c|c|c|}
\hline Null hypothesis & & No. of lag=2 & Critical value 0.01 \\
\hline & Likelihood ratio & Critical value 0.05 & 54.46 \\
\hline $\mathrm{r}=0$ & $100.8326^{* * *}$ & 47.21 & 35.65 \\
\hline $\mathrm{r} \leq 1$ & 17.02089 & 29.68 & 20.04 \\
\hline $\mathrm{r} \leq 3$ & 4.860039 & 15.41 & 6.65 \\
\hline
\end{tabular}

$* *(* * *)$ denotes rejection of the hypothesis at 5 percent (1 percent) significance level 
Table 6(b)

Normalized Cointegrating Coefficients Between the Unanticipated Changes in Money Supply M3 and the Composite Index (KLCI)

\begin{tabular}{|c|c|c|c|c|}
\hline $\log (\mathbf{K L C I})$ & $\log (\mathbf{U M 3})$ & $\log (\mathbf{G D P})$ & $\log (\mathbf{I N F})$ & $\mathbf{C}$ \\
\hline 1.000 & -13991.21 & -0.517555 & -2.508790 & 11.88586 \\
\hline & $(11863.8)^{* * *}$ & $(0.93684)$ & $(5.34635)^{* * *}$ & \\
\hline Loglikelihood & 1427.678 & & & \\
\hline
\end{tabular}

The value in the parentheses represents the estimated $t$ value of the normalized coefficients. The critical values are 2.576 for 1 percent $(* * *)$ and 1.960 for 5 percent $(* *)$ respectively.

Similarly, when the unanticipated changes in money supply M3 are used to represent the money channel in influencing the price of the composite index, the Likelihood Ratio is found to be significant at 5 percent significance level. The null hypothesis of no cointegrating vectors is rejected, indicating one cointegrating vector (refer to Table 6(a)). The estimated t value of the normalized cointegrating coefficient for the unanticipated changes in money supply M3 (11863.8) is positively significant and greater than the critical value of $t$ (2.576) for 1 percent significance level. In addition, the estimated $t$ value (5.34635) is greater than the critical value of $t(2.576)$ at 1 percent significance level. But the estimated t value (0.93684) is less than the critical value of $t(1.960)$ at 5 percent significance level. As such, the unanticipated changes in money supply M3 and the rate of inflation can influence the price of the composite index, unlike national income. The normalized coefficient sign for the unanticipated changes in money supply M3 is not in line with the theory except for the rate of inflation (refer to Table 6(b)).

The introduction of the rational expectation theory by converting the monetary aggregates of M1, M2 and M3 into anticipated and unanticipated reveals that the unanticipated changes in money supply M1, M2 and M3 support the non-neutrality theory of money. The findings support the study conducted by Barro (1977), Beladi and Samanta (1988) in India, Choudhry and Parai (1991) in Latin American countries and finally by Muzaffar and Ahmad (1997) in Malaysia. As such, it can be concluded that the money channel represented by the anticipated changes in money supply will not influence the price of indices in the long run, but the unanticipated changes in money supply are able to influence the price of indices in the long run. This is due to the level of monetization and the sophistication of the banking system in a nation. If the financial system of the country is well diversified and developed, it will be able to absorb the financial shocks in the country and money will be neutral in the long run. This can be supported by the influence of the rate of inflation in influencing the price of the indices. The rate of inflation is found to be important as it is claimed by Ghatak (1994) in countries that practice financial dualism, the existence of organized and non-organized financial sector in the economy. In addition, the unanticipated changes in money supply M1 are the only monetary aggregates that represented the money channel that had the correct coefficient sign in line with the economic theory. When the money supply increases, the rate of interest will decline. Demand for bonds will decrease, increasing the demand for stocks and finally leading to an increase in the price of stocks. This creates a positive relationship between the unanticipated changes in money supply M1 and the price of the indices. As for the rate of inflation, when the inflation rate increases, the government will practice a tight monetary policy. This will reduce money supply and increase the rate of interest. Demand for bonds will rise, but the demand for stocks will fall. The price of the stocks will also decline, thus creating a positive relationship between the rate of inflation and the price of the indices. This result was only found when the unanticipated changes in money supply M1 were used to represent the money channel. As such, it can be concluded that the best measurement of money supply M1 is supporting the findings of Muzaffar and Ahmad (1997) in explaining the behavior of the stock market.

\section{THE UNRESTRICTED VAR AND THE VECTOR ERROR CORRECTION MECHANISM (VECM) RESULT}

\section{The Money View Model}

The anticipated changes in money supply for monetary aggregates M1, M2 and M3 were unable to reject the null hypothesis of no cointegrating vectors. Since no cointegrating vectors were found in the long run, the shortrun dynamics between the stock prices and the anticipated changes in money supply were established using the unrestricted VAR. This is displayed in Tables 5.23 to 5.28. When the anticipated changes in money supply for all 
the monetary aggregates are replaced with the unanticipated changes in money supply M1, M2 and M3, the null hypothesis of no cointegrating vector was rejected at 1 percent significance level. This indicates at least one cointegrating vector was found for each monetary aggregate used to represent the unanticipated changes in money supply. Thus, the short-run dynamics between the unanticipated changes in money supply with both the indices are displayed in Table 1(a) to 6(b).

Table 7

The Unrestricted VAR Mechanism Between the Anticipated Changes in Money Supply M1 with the Composite Index (KLCI)

\begin{tabular}{|c|c|c|c|}
\hline Variable & Coefficient & Standard Error & t-ratio \\
\hline $\mathrm{D}(\log (\mathrm{KLCI}(-1))$ & 1.063382 & 0.09089 & $11.7002(* * *)$ \\
\hline $\mathrm{D}(\log (\mathrm{KLCI}(-2)$ & -2.39095 & 0.09495 & $-2.51814(* *)$ \\
\hline $\mathrm{D}(\log (\mathrm{AM} 1(-1))$ & 0.816764 & 0.22906 & $3.56574(* * *)$ \\
\hline $\mathrm{D}(\log (\mathrm{AM} 1(-2))$ & -0.616254 & 0.22733 & $-2.71089(* * *)$ \\
\hline $\mathrm{D}(\log (\mathrm{GDP}(-1))$ & -0.217371 & 0.31409 & -0.69207 \\
\hline $\mathrm{D}(\log (\mathrm{GDP}(-2))$ & 0.015314 & 0.30403 & 0.05037 \\
\hline $\mathrm{D}(\log (\mathrm{INF}(-1))$ & -0.002152 & 0.30036 & -0.00716 \\
\hline $\mathrm{D}(\log (\mathrm{INF}(-2))$ & -0.180869 & 0.29472 & -0.61369 \\
\hline $\mathrm{C}$ & 1.750359 & 0.81165 & $2.15655(* *)$ \\
\hline R square & 0.927043 & & \\
\hline
\end{tabular}

The value in the parentheses represents the estimated $t$ value of the normalized coefficients. The critical values are 2.576 for 1 percent $(* * *)$ and 1.960 for 5 percent $(* *)$ respectively.

Table 7 shows the unrestricted VAR between the anticipated changes in money supply M1 and the composite index. The t-ratio shows that the estimated $t$ value of the lagged one composite index (11.7002) and lagged two composite index (-2.51814) indicate that the null hypothesis of no short-run dynamics between these variables and the current composite index can be rejected at 1 percent and 5 percent significance levels. Therefore, it can be concluded that the lagged one and two of the composite index can influence the changes in the current composite index at 1 percent and 5 percent significance level respectively.

The anticipated changes in money supply M1 lagged one and two can influence the changes in the composite index at 1 percent significance level. The lagged one anticipated changes in money supply M1 have a significantly positive relationship with the composite index at 1 percent significance level because the estimated $t$ value of 3.56574 is greater than the critical value of $t$ (2.5760). This is found to be in line with the economic theory. The lagged two anticipated changes in money supply M1 have a significantly negative relationship with the composite index at 1 percent significance level because the estimated $t$ value of -2.71089 is greater than the critical value of $t$ (2.560). The sign of the coefficient is found to be in contrast with the economic theory. The constant is also found to be significant in explaining the changes in the composite index at 5 percent significance level. All other variables are insignificant in explaining the changes in the composite index at 1 percent significance level.

Table 8

The Unrestricted VAR Mechanism Between the Anticipated Changes in Money Supply M2 with the Composite Index (KLCI)

\begin{tabular}{|c|c|c|c|}
\hline Variable & Coefficient & Standard Error & t-ratio \\
\hline $\mathrm{D}(\log ($ KLCI(-1) & 1.115279 & 0.09540 & $11.6901^{* * *}$ \\
\hline $\mathrm{D}(\log (\mathrm{KLCI}(-2)$ & -0.183598 & 0.10035 & -1.82965 \\
\hline $\mathrm{D}(\log (\mathrm{AM} 2(-1))$ & 0.028882 & 0.09153 & 0.31555 \\
\hline $\mathrm{D}(\log (\mathrm{AM} 2(-2))$ & -0.041627 & 0.08653 & -0.48110 \\
\hline $\mathrm{D}(\log (\mathrm{GDP}(-1))$ & -0.073921 & 0.32264 & -0.22911 \\
\hline $\mathrm{D}(\log (\mathrm{GDP}(-2))$ & 0.080364 & 0.32186 & 0.24969 \\
\hline $\mathrm{D}(\log (\mathrm{INF}(-1))$ & -0.173008 & 0.63939 & -0.27058 \\
\hline $\mathrm{D}(\log (\mathrm{INF}(-2))$ & 0.103801 & 0.60637 & 0.17118 \\
\hline $\mathrm{C}$ & 0.876782 & 1.28201 & 0.68391 \\
\hline R square & 0.927043 & & \\
\hline
\end{tabular}

The value in the parentheses represents the estimated t value of the normalized coefficients. The critical values are 2.576 for 1 percent $(* * *)$ and 1.960 for 5 percent $(* *)$ respectively. 
Table 8 displays the unrestricted VAR between the anticipated changes in money supply M1 with the composite index. The estimated $t$ value (11.6901) is greater than the critical value of $t$ (2.560) for only the lagged one of the composite index at 1 percent significance level. Thus, the null hypothesis of no short-run relationship between the lagged one composite index with the current composite index can be rejected at 1 percent significance level. All other variables are insignificant in explaining the changes in the composite index at 1 percent significance level.

Table 9

The Unrestricted VAR Mechanism Between the Anticipated Changes in Money Supply M3 with the Composite Index (KLCI)

\begin{tabular}{|c|c|c|c|}
\hline Variable & Coefficient & Standard Error & t-ratio \\
\hline $\mathrm{D}(\log (\mathrm{KLCI}(-1))$ & 1.075941 & 0.09397 & $11.4502^{* * *}$ \\
\hline $\mathrm{D}(\log (\mathrm{KLCI}(-2)$ & -0.171937 & 0.09923 & -1.73274 \\
\hline $\mathrm{D}(\log (\mathrm{AM} 3(-1))$ & 1.740613 & 0.78735 & $2.21072^{* *}$ \\
\hline $\mathrm{D}(\log (\mathrm{AM} 3(-2))$ & -1.710971 & 0.78803 & $-2.17121^{* *}$ \\
\hline $\mathrm{D}(\log (\mathrm{GDP}(-1))$ & -0.095689 & 0.33560 & $-2.28512^{* *}$ \\
\hline $\mathrm{D}(\log (\mathrm{GDP}(-2))$ & 0.065271 & 0.31734 & 0.20568 \\
\hline $\mathrm{D}(\log (\mathrm{INF}(-1))$ & 0.010396 & 0.30837 & -0.55291 \\
\hline $\mathrm{D}(\log (\mathrm{INF}(-2))$ & -0.168956 & 0.30558 & 1.27125 \\
\hline $\mathrm{C}$ & 1.278678 & 1.00584 & \\
\hline
\end{tabular}

The value in the parentheses represents the estimated $t$ value of the normalized coefficients. The critical values are 2.576 for 1 percent $(* *)$ and 1.960 for 5 percent $(* *)$ respectively.

Table 9 shows the unrestricted VAR between the anticipated changes in money supply M3 with the composite index. The one lagged of the composite index is positively significant in explaining the changes in the current composite index at 1 percent significance level when the estimated $t$ value of 11.4502 is found to be greater than the critical value of $t$ (2.560). The null hypothesis of no short-run relationship between the variables can be rejected at 1 percent significance level. Lagged one and two of the anticipated changes in money supply M3 are also found to be negatively significant in explaining the changes in the composite index at 5 percent significance level. As for the lagged one national income, it is found to be positively significant in explaining the changes in the composite index at 5 percent significance level. This is because the estimated $t$ value for the lagged one anticipated changes in money supply M3 (-2.21072), the lagged two anticipated changes in money supply M3 (-2.17121), and the lagged one national income (-2.28512) have an estimated $t$ value greater than the critical value of $t(1.960)$, indicating the null hypothesis of no short-run relationship between these variables and the composite index can be rejected at 5 percent significance level.

Table 10

The VECM Between the Unanticipated Changes in Money Supply M1 with the Composite Index (KLCI)

\begin{tabular}{|c|c|c|c|}
\hline Variable & Coefficient & Standard Error & t-ratio \\
\hline EC term & -0.001376 & 0.00961 & -0.14315 \\
\hline $\mathrm{D}(\log (\mathrm{KLCI}(-1))$ & 0.127352 & 0.09809 & 1.29829 \\
\hline $\mathrm{D}(\log (\mathrm{KLCI}(-2)$ & 0.062548 & 0.09775 & 0.63985 \\
\hline $\mathrm{D}(\log (\mathrm{UM} 1(-1))$ & 2.827599 & 5.30936 & 0.53257 \\
\hline $\mathrm{D}(\log (\mathrm{UM} 1(-2))$ & 1.675375 & 3.80044 & 0.44084 \\
\hline $\mathrm{D}(\log (\mathrm{GDP}(-1))$ & -0.040623 & 0.33207 & -0.12233 \\
\hline $\mathrm{D}(\log (\mathrm{GDP}(-2))$ & 0.270363 & 0.32845 & 0.82314 \\
\hline $\mathrm{D}(\log (\mathrm{INF}(-1))$ & 0.013581 & 0.32068 & 0.04235 \\
\hline $\mathrm{D}(\log (\mathrm{INF}(-2))$ & -0.10561 & 0.31640 & -0.33379 \\
\hline $\mathrm{C}$ & 0.000712 & 0.01012 & 0.07038 \\
\hline
\end{tabular}

The value in the parentheses represents the estimated t value of the normalized coefficients. The critical values are 2.576 for 1 percent $(* * *)$ and 1.960 for 5 percent $(* *)$ respectively. 
The error correction term found in Table 10 shows that the estimated $t$ value of -0.14315 is less than the critical value of $\mathrm{t}$ that is 1.960 at 5 percent significance level. As such, it can be concluded that the null hypothesis of no short-run dynamics between the unanticipated changes in money supply M1 and the composite index cannot be rejected. All other variables are also found to be insignificant in explaining the changes in the composite index at 5 percent significant level because the estimated $t$ value is less than the critical value of $t(1.960)$.

Table 11

The VECM Between the Unanticipated Changes in Money Supply M2 with the Composite Index (KLCI)

\begin{tabular}{|c|c|c|c|}
\hline Variable & Coefficient & Standard Error & t-ratio \\
\hline EC term & 0.004351 & 0.00458 & 0.95010 \\
\hline $\mathrm{D}(\log (\mathrm{KLCI}(-1))$ & 0.138547 & 0.09897 & 1.39988 \\
\hline $\mathrm{D}(\log (\mathrm{KLCI}(-2)$ & 0.037198 & 0.09987 & 0.37246 \\
\hline $\mathrm{D}(\log (\mathrm{UM} 2(-1))$ & -0.068003 & 0.05153 & -1.31960 \\
\hline $\mathrm{D}(\log (\mathrm{UM} 2(-2))$ & -0.005759 & 0.02239 & -0.25719 \\
\hline $\mathrm{D}(\log (\mathrm{GDP}(-1))$ & -0.052275 & 0.33083 & 0.15801 \\
\hline $\mathrm{D}(\log (\mathrm{GDP}(-2))$ & 0.274242 & 0.32727 & 0.83797 \\
\hline $\mathrm{D}(\log (\mathrm{INF}(-1))$ & 0.103170 & 0.64681 & 1.04869 \\
\hline $\mathrm{D}(\log (\mathrm{INF}(-2))$ & 0.665016 & 0.63414 & 0.14500 \\
\hline $\mathrm{C}$ & 0.001466 & 0.01011 & \\
\hline
\end{tabular}

The value in the parentheses represents the estimated t value of the normalized coefficients. The critical values are 2.576 for 1 percent $(* * *)$ and 1.960 for 5 percent $(* *)$ respectively.

Similarly, when the unanticipated changes in money supply M2 are used, the estimated t value for the error correction term (0.95010) is also found to be less than the critical value of $t(1.960)$ at 5 percent significance level. Thus, it can be concluded that the null hypotheses of no short-run dynamics between the composite index and the unanticipated changes in money supply M2 can be rejected. In addition, all other variables are also found to be insignificant in explaining the changes in the price of the composite index at 5 percent significance level (refer to Table 11).

Table 12

The VECM Between the Unanticipated Changes in Money Supply M3 with the Composite Index (KLCI)

\begin{tabular}{|c|c|c|c|}
\hline Variable & Coefficient & Standard Error & t-ratio \\
\hline EC term & -0.004314 & 0.00409 & -1.05441 \\
\hline $\mathrm{D}(\log (\mathrm{KLCI}(-1))$ & 0.157231 & 0.09688 & 1.62297 \\
\hline $\mathrm{D}(\log (\mathrm{KLCI}(-2)$ & 0.042420 & 0.09074 & 0.43850 \\
\hline $\mathrm{D}(\log (\mathrm{UM} 3(-1))$ & -15.59958 & 71.2022 & -0.21909 \\
\hline $\mathrm{D}(\log (\mathrm{UM} 3(-2))$ & -48.740097 & 52.0635 & -0.93618 \\
\hline $\mathrm{D}(\log (\mathrm{GDP}(-1))$ & -0.006900 & 0.32999 & -0.02091 \\
\hline $\mathrm{D}(\log (\mathrm{GDP}(-2))$ & 0.208183 & 0.32742 & 0.63583 \\
\hline $\mathrm{D}(\log (\mathrm{INF}(-1))$ & 0.111003 & 0.31666 & 0.35054 \\
\hline $\mathrm{D}(\log (\mathrm{INF}(-2))$ & -0.141155 & 0.31030 & -0.45490 \\
\hline $\mathrm{C}$ & 0.001018 & 0.01001 & 0.10167 \\
\hline
\end{tabular}

The value in the parentheses represents the estimated $t$ value of the normalized coefficients. The critical values are 2.576 for 1 percent $(* * *)$ and 1.960 for 5 percent $(* *)$ respectively.

In Table 12, the error correction term is insignificant in explaining the changes in the composite index. The estimated $t$ value of -1.05441 is less than the critical value of $t(1.960)$ at 5 percent significance level. Thus, the null hypothesis that there are no short-run dynamics between the price of the composite index and the unanticipated changes in money supply M3 cannot be rejected. All other variables are also found to insignificant in explaining the changes in the composite index because the estimated $t$ value is less than the critical value of $t$ at 5 percent significance level. 
The findings claim that the anticipated changes in money supply are able to influence the composite index in the short run supporting the claim that money is not neutral in the short run; but the unanticipated changes in money supply does not influence the prices of both the indices in the short run, supporting the claim that money is neutral in the short run. This is due to the process of eliminating the discrepancies in the money market played by the central bank and the financial institutions in Malaysia. This is because the process of elimination of the excess balance can change the role of money as an active or passive player in the economy. Since there are no short-run dynamics between the unanticipated changes in money supply and the price of the indices, it can be concluded that unanticipated money supply is passive and the central bank is able to eliminate any form of excess balance and would not be able to create any aggregate short-run consequences. In contrast, the anticipated changes in money supply are active in the short run, and it is intended to create aggregate short-run consequences in order to stabilize the economy of the nation that would eventually influence the price of both the indices.

\section{CONCLUSION}

This study aims to establish a relationship between the monetary transmission channels with the stock prices. The development of the financial institution has changed the importance of certain monetary transmission channels. Initially, the concentration of the financial institution in Malaysia comprises mainly of the money market, or preferably known as the commercial banks. Money market deals with short term loanable funds until now performed the function of rationally allocating funds in Malaysia. But recently the concentration began to diversify to other financial institutions, like the capital market in mobilizing funds for the long run. Therefore, the importance of the monetary transmission in influencing the behavior of the economy has changed from the money channel, interest rate channel and the exchange rate channel to the credit channel.

The money market functions as a tool to promote financial stability to transfer funds to the growth of firms dealing with important sectors. The growth of these firms will be shown in the performance of their stock prices. This will eventually make the money market a complement to the capital market that deals with long term funds. In addition, the successful implementation of the monetary policy through the monetary transmission channels and its effectiveness of absorbing unanticipated changes in the economy depend on the diversification and sophistication of the lending channels in Malaysia.

The previous studies conducted by Muzaffar and Ahmad (1997), Fauzias, Nor Azuddin and Zaidi (2000) and Rim (2000) in Malaysia only explored monetary transmission channels, like the money channel, the interest rate channel, and the exchange rate channel, with the composite index. In this study, an exhaustive analysis was used by incorporating the rational expectation theory by distinguishing the money channel into anticipated changes in money supply and unanticipated changes in money supply for all the monetary aggregates M1, M2 and M3.

Before beginning the analysis, a unit root using the Augmented Dickey Fuller test and the Philip Perron test was conducted. The results revealed that all the time series are non-stationary at the level form, except for the unanticipated changes in money supply M1, M2 and M3. After the first difference, all the variables were found to be stationary. This is followed by the Johansen Cointegration test to determine the existence of a long-run relationship, while the Vector Error Correction mechanism or the unrestricted VAR is used to find the short-run dynamics between the monetary transmission channels with the price of the indices. The results revealed that the monetary aggregates M1, M2 and M3, which were used to represent the money channel, failed to establish a longrun relationship with the composite index but established a short-run relationship with the composite index. The short-run relationship between the unanticipated changes in money supply and the price of both the indices could not be established. In contrast, when the anticipated changes in money supply were replaced with the unanticipated changes in money supply, a long-run relationship was established with the price of both the indices; but the shortrun dynamic between the unanticipated changes in money supply and the price of the indice could not be established. The findings support the study conducted by Muzaffar and Ahmad (1997), Barro (1997), Barro and Rush (1980), Artfield (1981), Conarella and Gorston (1983), and Chein and Steindl (1987). The researchers claim that in developing nations, unanticipated changes in money are active or non-neutral in the long run, but anticipated changes in money are active or non-neutral in the short run. This is because the level of monetization is less in the developing nations. This reflects the inability of the financial institutions to eliminate any excess in the money market in the long run. Beladi and Samanta (1988) in India and Choudhry and Parai (1991) in Latin American 
countries also found the evidence of non-neutrality.

\section{AUTHOR INFORMATION}

Dr. Caroline Geetha. Currently a senior lecturer in University Malaysia Sabah, Kota Kinabalu, Sabah, Malaysia. I have obtained my bachelors, masters and also Phd from the field of monetary economics. The institution that awarded all my degrees is the National University of Malaysia. I have an experience of 17 years in teaching monetary economics and 10 years of doing research in the field of monetary economics.

\section{REFERENCES}

1. Achjar Lijas.1998. The transmission of monetary policy in Indonesia, BIS Policy Paper 3, Bank of International Settlement, BIS press.

2. Anderson, L.C. and Jordan, J. L. 1967. Money in a modern quantity theory framework, Federal Reserve Bank of St. Louis Review 49:pp 4-5.

3. Attfield, C.L.F. and D. Demery. 1981. Rational expectations in macroeconomics: An introduction to theory and evidence, Oxford U.K: basil Blackwell.

4. Arize, Augustine C. 1993. Determinants of Income Velocity in the United Kingdom: Multivariate Granger Causality, American Economists 37: pp. 40-45.

5. Bailey, Warren. 1988. Money Supply Announcements and Exante Volatility of Asset Prices, Journal of Money, Credit and Banking, Vol. 20, No. 4.

6. Barro, Robert J. 1977. Unanticipated Money Growth and Unemployment in the United States, American Economic Review 67: pp 101-115.

7. Beladi, H. and Samanta, S. 1988. Unanticipated Monetary Policy: Another Look for a Developing Country, Journal of Macroeconomics, Vol.10. pp. 297 - 307.

8. Boyle, W. Glenn and Young, Leslie. 1999. Monetary Rules and the Stock Market Value, Journal of Economics and Business 51: pp. 365-372.

9. Bernanke, B. and Blinder, A. 1992. The Federal Funds Rate and the Channel of Monetary Transmission, American Economic Review 82: pp.901-921.

10. Bernanke, B. and M. Gertler. 1995. Inside the black box: The credit channel of monetary policy transmission, Journal of Economic Perspectives. 9: pp.27-48

11. Christiano, L. and M. Eichenbaum. 1992. Liquidity Effects and the Monetary Transmission Mechanism, American Economic Review Papers and Proceedings 82:pp. 346-353.

12. Cassey Lee. 2001. Impact of globalization and liberalization on the financial services sector, Banker's Journal Malaysia, Institute Bank-bank Malaysia: pp. 39-48.

13. Choudhry, Taufiq. 1996. Real stock prices and the long-run money demand function: Evidence from Canada and the USA, Journal of International Money and Finance, Vol15. No.1 : PP. 1-17.

14. Cornell, B. 1983a. Money supply announcements and interest rates: Another view, Journal of Business 56:pp1-23.

15. Cornell, B. 1983b. The money supply announcement puzzle: Review and interpretation, American Economic Review 83: pp.644-657.

16. Cooper, R.V.L. 1972. Efficient Capital Markets: A review of theory and empirical work, Journal of Finance 5: pp. 383-417.

17. Conarella, Giorgio and Stephen K. Pollard 1989. Unanticipated monetary growth, output and the price in Latin America; An Empirical investigation, Journal of Development Economics, Vol. 30, No. 2: pp. 345358.

18. Choudhry, M.A. and Parai, A.K. 1991. Anticipated Monetary Policy and the real .output: Evidence from the Latin American Countries, Applied Economics. Vol.23. pp 579 -586.

19. Davis, M. and Tanner, E. 1997. Money and Economics Activity revisited, Journal of International Money and Finance 16; PP. 955-968.

20. Darrat, Ali F. 1988. On Fiscal Policy and the Stock Market, Journal of Money, Credit and Banking, Vol. 20 No. 3.

21. Darrat, AliF. And M. Osman Suliman. 1994. Volatility Money Growth and the U.S. Velocity Puzzle: Some Further Results, Journal of Economics and Business, 46, pp77-87. 
22. Dickey, D. A. and W. A. Fuller. 1979. Distribution of the Estimators for Autoregressive Time Series with a Unit Root, Journal of the American Statistical Association, 74, pp427-431.

23. Domac, I.1999. Did the East Asian Crisis Disproportionately Hit Small Business in Korea? Economic Notes, Vol. 28. Issue 3: pp. 403

24. Fama, Eugene. F. and G. William Schwert. 1977. Asset Returns and Inflation, Journal of Financial Economics 5 : pp. 115-146.

25. Fauzias Mat Nor, Noor Azuddin Yakob, Zaidi Isa. 2000. Arch and Garch based tests on the Malaysian Stock Market, Interest Rate and Exchange Rate before and during the currency turmoil, Capital Market Review. Vol.7: pp. 87-99.

26. Feldstein, M. 1980. Stock Returns and the Weekend Effect, Journal of Financial Economics 8: pp. 55 - 69.

27. Freidman, Milton. 1983. Monetary Variability: United States and Japan, Journal of Money, Credit and Banking, 15, pp339-343.

28. Friedman, Milton. 1983. Monetary Variability: United States and Japan, Journal of Money, credit and Banking 15: pp. 339-343

29. Friedman and Schwartz. 1963. Money and Business Cycles, Review of Economics and Statistics 45: pp.3264

30. Gertler, Mark and Gilchrist, Simon. 1993. The role of credit market imperfections in the monetary transmission mechanism: Arguments and Evidence. Scandinavian Journal of Economics. Vol 95. Issue 1: pp. 43.

31. Ghatak, Subrata.1994. An introduction to development economics, Routledge, London.

32. Granger, C. W. J. 1988. Some recent Development in the Concept of Causality, Journal of Econometrics, Vol. 39, pp 199-211.

33. Grossman, J. 1981. The rationality of money supply expectations and interest rates to monetary surprises, Journal of Money, Credit and Banking 13 : pp. 409-424.

34. Gosh, B.N. and S. C. Gan. 1994. On the Choice of Appropriate Money Stock for Malaysia, The Indian Journal of Economics LXXV: pp. 269-278.

35. Gurley, G.J. and Shaw, S.E. 1967. Financial structure and economic development, Economic Development and Culture Change, 15: pp.257-268.

36. Gurley, G.J. and Shaw, S.E. 1960. Money in a theory of finance, Brookings Institute, Washington.

37. Hanson, James. A. 1980. The short run relationship between growth and inflation in Latin America, American Economic Review, Vol. 70: pp. 972-989.

38. Ho, Y.K. 1983. Money supply and Equity Prices: An Empirical Note on Far Eastern Countries, Economic Letters 11: PP. 161-165.

39. Hardouvelis, Gikas A. 1985a. Economic news, exchange rates and interest rates, First Boston Working Paper Series 86-12, Colombia University Graduate School of Business.

40. Hardouvelis, Gikas A. 1987. Reserve Announcements and Interest Rates: Does Monetary Policy Matter?, Journal of Finance 42 (2).

41. Homa, E. Kenneth and Jaffe, M. Dwight. 1971. The Supply of Money and Common Stock Prices, Journal of Finance, pp. 1056-1066.

42. Hamburger, Michael J., and Levis A. Kochin. 1972. Money and Stock Prices: The Channels of Influence, Journal of Finance 27: pp. 231-249.

43. Johansen, S. 1988. Statistical Analysis of Cointegration Vectors, Journal of Economic Dynamics and Control, 12, pp 231-254.

44. Johansen, S. and K. Juselius. 1990. Maximum Likelihood Estimation and Inference on Cointegration with Applications to the Demand for Money, Oxford Bulletin of Economics and Statistics, 52, pp 169-211.

45. Jones, J.D. and N. Uri. 1987. Money supply growth, Stock Returns and the Direction of Causality, SocioEconomic Planning Science 21: pp. 321-325.

46. Kasumovich, Marcel. 1996. Interpreting Money Supply and Interest Rate Shocks as Monetary Policy Shocks, Bank of Canada Working Paper 96-98.

47. Kaminsky, Graciela L. and Lewis, Karen K. 1996. Does foreign exchange intervention signal future monetary policy?, Journal of Monetary Economics 37: pp. 285-315.

48. Keran, M.W. 1971. Expectations, money and stock prices, Federal Reserve Bank of St. Louise Review 53:pp. 16-31. 
49. Laidler, D. 1971. The influence of money on economic activity: A survey of current problems in Monetary Theory and Policy in the 1970s, Oxford University Press, Oxford.

50. Lastrapes, W. and G. Selgin. 1995. The Liquidity Effect; identifying Short Run Interest Rate Dynamics Using Long Run Restrictions, Journal of Macroeconomics 17: pp. 387-404.

51. Leeper, E. and D. Gordon. 1992. In Search of the Liquidity Effect, Journal of Monetary Economics 29; pp. 341-369.

52. Lucas, R. E. 1972. Expectations and the Neutrality of Money, Journal of Economic Theory 4. pp.103-24.

53. Modigliani, F. and Cohn, R. 1979. Inflation, Rational Expectations and the term structure of interest rates, Economica 40: pp. 12-43.

54. Mullineaux, D. J. 1978. On Testing for Rationality: Another Look at the Livingston Price Expectations Data, Journal of Political Economics 86: pp. 329-336.

55. Mac Kinnon, J. 1991. Critical Value for Cointegration Tests in R.F. Engle and C. W. J. Granger. Long run Economic Relationships: Reading in Cointegration, New York: Oxford University Press.

56. Mc Cornac, Dennis. C. 1994. Velocity and Money Growth Variability: Evidence from Japan, Applied Economics Letters, 1, pp145-147.

57. Mishkin, Frederic S. 1982. Does Anticipated Monetary Policy Matter?, An Econometric Investigation, Journal of Political Economy 90:pp. 22-51.

58. Mishkin, Federic S. 1982. Does Anticipated Monetary Policy Matter? An Empirical Investigation, Journal of Political Economy, 90, pp 22-51.

59. Modigliani, F and Cohn, R. 1979. Inflation, rational expectations and the term structure of interest rates, Economica 40: pp. 12-43.

60. Mc Cornac, D. 1991. Money and the level of stock market prices: Evidence from Japan, Quarterly Journal of Business and Economics 30 : pp. 42-51.

61. Marasded, O. 1993. Anticipated and unanticipated money. A Case Study of Malaysia, Applied Economics. Vol.25. pp. 919-925.

62. Mc Phail, Kim 2000 Broad Money: A Guide for Monetary Policy, Bank of Canada Manuscript.

63. Muzaffar Shah Habibullah and Ahmad Zubaidi Baharumshah. 1997. Divisia Monetary Aggregates and Stock Prices in Malaysia: An Empirical Note, Capital Market Review, Kuala Lumpur Stock Exchange and RIIAM: pp. 53-65.

64. Mundell, R. 1963. Inflation and Real Interest, Journal of Political Economy 71: pp.280-283.

65. Osterwald-Lenum, M. 1992. A note with Quantities of the Asymptotic Distribution of the Maximum Likelihood Cointegration Rank Test Statistics, Oxford Bulletin of Economics and Statistics, 54, pp 461-472.

66. Osterwald- Lenum, Michael. 1992. A note with quantiles of the asymptotic distribution of the maximum likelihood cointegration rank test statistics: Four cases, Oxford Bulletin of Economics and Statistics 54:pp. 461-472.

67. Obiyathullah Ismail Bacha and Ruzita Md. Azim 2001. Financial Liberalisation and Currency Vulnerability, Bankers Journal, Institute Bank-Bank Malaysia : pp. 10-21

68. Phelps, E.S. 1973. Inflation in the theory of public finance, Swedish Journal of Economics 75. pp. 67-82.

69. Philips, P.C.B. and P.Perron. 1988. Testing for Unit Root in the Time Series Regression, Biometrika, 75, pp 335-346.

70. Palmer, Michael. 1970. Money supply, portfolio adjustments and stock prices, Financial Analyst Journal: pp. 19-22.

71. Pepper, G and Wood, G.E. 1976. Too Much Money?, Institute of Economic Affairs, Hobart Paper No. 68, IEA, London.

72. Roley, V.V. 1982. Weekly money supply announcements and the volatility of short term interest rates, Federal Reserve Bank of Kansas City, Economic Review 67: pp. 3-15.

73. Rapach, David E. 2001. Macro shocks and real stock prices, Journal of Economics and Business 53: pp 526.

74. Rim, Hong. 2002. The effect of the real exchange rate on the stock market in Malaysia, Journal of International Business and Economics, Summer edition.

75. Rozeff, S. Michael. 1975. The money supply and the stock market: The Demise of a Leading Indicator, Financial Analysts Journal.

76. Sargent, T.J. and Wallace, N. 1975. Rational expectations, the optimal monetary instrument and the optimal money supply rule, Journal of Political Economics 83. pp. 241-254. 
77. Sprinkel, Beryl W. 1964. Money and Stock Prices, Homewood, ILL: R.D.Irwin

78. Shehy, Edmund. 1980. Money, income and prices in Latin America: An Empirical Note, Journal of Development Economics, Vol. 7: pp. 334 - 357.

79. Semudram, Yap and Azidin. 1993. A Vector Autoregression Approach to Modelling the Malaysian, First Malaysian Economic Conference, Malaysian Institute of Economic Research Conference Papers.

80. Summers, L. H. 1981. Inflation and the Valuation of Corporate Equities, National Bureau of Economic Research, Working Paper No. 824.

81. Schiller, R. 1989. Market Volatility, MIT Press, Cambridge, MA.

82. Schumpeter, J.A. 1911. The theory of economic development, Cambridge: Harvard Institute Press.

83. Schwartz, G. 1978. Estimating the dimension of a model. Annals of Statistics 6:pp. 461-464.

84. Sims, C. A. and T. Zha. 1995. Error Bands for Impulse Responses, Federal Reserve bank of Atlanta Working Paper No 95-96.

85. Tan Hui Boon and Law Siong Hook. 2000. Money Velocity, Volatility and Policy: An empirical study based on the GARCH model. The Journal of the Institute of Bankers Malaysia, 116, pp 13-21.

86. Taylor, J. B. 1975. Monetary policy during a transition to rational expectations, Journal of Political Economics 83, pp.1009-21.

87. Thornton, John and Molyneux, Philips. 1995. Velocity and the Volatility of Unanticipated and Anticipated Money Supply in the United Kingdom, International Economics Journal, Vol. 9. No. 3.

88. Thornton, John.1991. Velocity and the Variability of Monetary Growth in the United Kingdom, Applied Economics, 23, pp 811-813.

89. Thorbecke, Willem and Alami. 1994. The Effect of Changes in the Federal Funds Rate Target on Stock Prices in the 1970s, Journal of Economic Business 46: pp. 13 - 19.

90. Tobin, James. 1969. A General Equilibrium Approach to Monetary Theory, Journal of Money, Credit and banking 1: pp.15-29.

91. Urich, T. and Wachtel, P. 1981. Market Response to the weekly money supply. Announcements in the 1970s, Journal of Finance 36, pp. 1063 - 1072.

92. Yusuff, Mohammed B. 1988. Money, prices and balance of payments in Malaysia, The Indian Economic Journal, Vol. 36, No. 1: pp. 33-47.

93. Yusuff, Mohammed B. 1993. Rational Expectations, Money Growth and Output in Malaysia, First Malaysian Econometric Conference, The Crown Princes Kuala Lumpur, 6-7 April 1993.

94. Walsh, Carl E. 1984. Interest Rate Volatility and Monetary Policy, Journal of Money, Credit and Banking 16: pp. 133-150.

95. Wald, R. 1970. Public interpretation of Federal Reserve Discount rate changes. Evidence on the "announcement effect", Econometrica 38; pp. $231-250$.

96. 1999. The Central Bank and the Financial System of Malaysia, Bank Negara Malaysia, Kuala Lumpur.

97. _ Monthly Bulletin, various issues, Bank Negara Malaysia, Kuala Lumpur.

98. 1988. Unanticipated money, price levels and output in Malaysia, Department of Economics, Universiti Pertanian Malaysia.

99. 1991. Money growth, output and price: Evidence from Malaysia, Department of Economics, Universiti Pertanian Malaysia. 